\title{
INTERNATIONAL COMMERCIAL ARBITRATION AND THE CANADIAN EXPERIENCE
}

\section{DAVID R. HAIGH, Q.C., ALICIA K. KUNETZKI AND CHRISTINE M. ANTONY*}

International Commercial Arbitration although enjoying a long pedigree, has only recently become a "hot topic." This is due to the growing trends towards institutionalizing and unifying ICA processes.

These trends are signified by the rise in private, neutral arbitration institutions and by the adoption, in many states, of international conventions and model laws. The unification of laws is the most recent process in this trend.

These trends are all examined in some detail. It is noted how the lex arbitri, or law of the situs of the arbitration, can affect the rules and procedures of the arbitration. The UNCITRAL Model Law is examined as the key example of the unification of laws movement. The alternative dispute resolution provision of NAFTA is also commented on.

The authors then focus specifically on Canada's contributions to and participation in ICA. In an important closing section, Canadian jurisprudence interpreting the new Canadian ICA legislation is comprehensively surveyed. The authors conclude by giving an outlook on the future of ICA and Canada's role therein.
L'arbitrage commercial international (ACI), bien qu'institué depuis longtemps, est devenu tout récemment un sujet "à la page». Ce nouvel intérêt est dî $\dot{a}$ une tendance accrue vers l'institutionnalisation et l'uniformisation des processus d'ACI. Elle se traduit par une augmentation du nombre de conseils d'arbitrage neutres privés, et par l'adoption, dans de nombreux États, de conventions internationales et de lois types. L'uniformisation des lois est le phénomène le plus récent à cet égard.

Ces tendances font l'objet d'un examen dètaillé. Les auteurs notent comment la lex arbitri, ou loi du lieu d'arbitrage, peut influer sur les règles et procédures d'arbitrage. L'Élaboration d'un projet de loi type de la CNUDCI est examiné à titre d'exemple-clé du mouvement d'uniformisation des lois. Les dispositions relatives au règlement des différends de l'ALÉNA sont également étudiées.

Les auteurs se penchent ensuite sur les contributions et la participation du Canada à l'ACI. Ils procèdent enfin à un examen approfondi de la jurisprudence canadienne interprétant la nouvelle législation canadienne d'ACI. Les auteurs concluent en offrant un aperçu de l'avenir de l'ACI et du rôle du Canada dans ce cadre.

\section{TABLE OF CONTENTS}

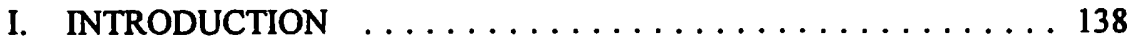

II. THE INTERNATIONAL ENVIRONMENT $\ldots \ldots \ldots \ldots \ldots \ldots 139$

A. A FRAMEWORK FOR ANALYSIS $\ldots \ldots \ldots \ldots \ldots \ldots 139$

B. INTERNATIONAL COMMERCIAL

ARBITRATION DEFINED ................. 143

C. THE PARADIGM: FREEDOM OF CONTRACT

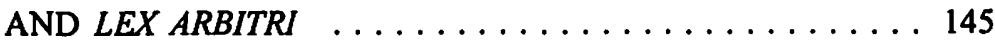

D. THE PROCESS OF UNIFICATION -

THE NEXT STEP . . . . . . . . . . . . . . . . 153

E. NORTH AMERICAN FREE

TRADE AGREEMENT $\ldots \ldots \ldots \ldots \ldots \ldots \ldots \ldots 155$

III. THE CANADIAN EXPERIENCE $\ldots \ldots \ldots \ldots \ldots \ldots \ldots \ldots 156$ 
A. CANADA'S INDUCTION INTO THE MODERN WORLD OF INTERNATIONAL

COMMERCIAL ARBITRATION ............. 156

B. THE JUDICIARY'S RESPONSE: CREATING

A FAVOURABLE ENVIRONMENT FOR THE

SETTLEMENT OF INTERNATIONAL

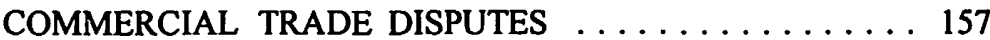

IV. CONCLUSION

\section{INTRODUCTION}

It would seem that the topic of international commercial arbitration is highly in vogue these days. Since the early 1980s, there has been an explosion of academic and journalistic writings on the topic, ranging from the history of international commercial arbitration, to specific arbitral procedural rules, international conventions and the enforcement of arbitral awards. It is fair to say that today's interest in the topic is a product of the international commercial environment, the growing insignificance of national economic boundaries, the increasing economic and political interdependence of nations, the need for large scale infrastructure developments in third world countries and technological advances in world communication and travel. For, the fact of the matter is, international commercial arbitration is not a new world phenomenon. The process of resolving disputes in a private manner with the aid and direction of a neutral third party is as old as international commercial trade itself.'

What is new is the increasing institutionalized nature of international commercial arbitration and the process of unification of national laws to facilitate the resolution of international commercial disputes. International commercial arbitration today is more sophisticated, legalistic, complex and institutionalized. ${ }^{2}$ As a topic of study, it is a study of process. The resolution of a dispute itself is secondary to this. We are interested in international commercial arbitration as a means to an end, as an approach to "doing business," and as a paradigm for commercial trading in the international realm. The end is the smooth functioning of international commercial trade and the generation of wealth; the approach is internationalism in conduct and interpretation; and the paradigm is freedom of contract, party autonomy and lex arbitri.

Canada's own experience in this process is of relatively recent origin. Although domestic arbitration has occurred in Canada for many years, international arbitration was rare prior to 1986 when the federal government, the provinces and the territories

1 Some arbitral courts, such as the centre in Stockholm, claim their origins in arbitral procedures which are several hundred years old. Wherever Islamic law or traditions prevail, the claim is made, with legitimacy, that settling disputes with the assistance of a neutral third party was promulgated by the Prophet.

2 A. Redfern, M. Hunter \& M. Smith, Law and Practice of International Commercial Arbitration, 2d ed. (London: Sweet \& Maxwell, 1991) at 3. 
acceded to the New York Convention ${ }^{3}$ and adopted the UNCITRAL Model Law. ${ }^{4}$ Despite the passage of this legislation, international commercial arbitration remains an unusual occurrence in Canada. Further, the Canadian courts have had few opportunities to interpret and apply the new law. To date, there are fewer than fifteen reported cases, four of which are from various appellate courts. ${ }^{5}$ No case involving the various international commercial arbitration Acts now in force in Canada has as yet been before the Supreme Court of Canada.

This article will focus on the institutionalization and unification process in international commercial arbitration generally, followed by a review and analysis of the Canadian experience. We conclude with the realistic position that international commercial arbitration in Canada and around the world is an ever evolving system for the resolution of disputes that, like any system, is neither perfect nor utopian. But somehow, it works fairly well.

\section{THE INTERNATIONAL ENVIRONMENT}

\section{A. A FRAMEWORK FOR ANALYSIS}

To facilitate the dictates of international commerce, we have created a complex, multi-layered system for the resolution of international commercial disputes. The process of institutionalization has been somewhat haphazard, as have many developments in the international realm. In the words of one author's incisive analogy, we are "like a breed of spiders that can spin vast webs in the night but have trouble finding our way through them by day." In international commercial arbitration, our collective ad hoc efforts at developing procedures which are effective and commonly recognized are only gradually bearing fruit. For example, in even a simple case, many laws will potentially govern the resolution and determination of the dispute: (1) the agreement between the parties, including choice of law and choice of forum, if any; (2) the arbitral rules and procedures; (3) the rules of the institution or centre chosen to

Convention on the Recognition and Enforcement of Foreign Arbitral Awards, New York, 10 June 1958, 330 U.N.T.S. 38 [hereinafter the New York Convention].

United Nations Commission on International Trade Law (UNCITRAL), UNCITRAL Model Law on International Commercial Arbitration, Annex I, UN Doc. A/40/17 (1985) [hereinafter UNCITRAL Model Law or Model Law]. For the federal, provincial and territorial enactments of the Model Law, see Graham, infra note 76, 7n.

Kaverit Steel and Crane Lid. v. Kone Corp. (1992), 120 A.R. 346 (C.A.); Automatic Systems Inc. v. Bracknell Corp. (1994), 13 C.L.R. (2d) 171, 18 O.R. (3d) 257 (C.A.); Quintette Coal Ltd. v. Nippon Steel Corp., [1991] 1 W.W.R. 219, 50 B.C.L.R. (2d) 207 (C.A.), aff'g (1990), 47 B.C.L.R. (2d) 201 (S.C.), leave to appeal to S.C.C. refused (1990), 50 B.C.L.R. (2d) xxviii; BWV Investments Lid. v. Saskferco Producls Inc., [1995] 2 W.W.R. 1 (Sask. C.A.); see also Boart Sweden $A B$ v. NYA Stromnes $A B$ (1988), 41 B.L.R. 295 (Ont. H.C.J.); Globe Union Industrial Corp. v. G.A.P. Marketing Corp., [1995] 2 W.W.R. 696 (B.C.S.C.); Dunhill Personnel System Inc. v. Dunhill Temps Edmonton Ltd. (1994), 13 Alta. L.R. (3d) 241 (Q.B.); Kanto Yakin Kogyo Kabushiki-Kaisha v. Can-Eng Manufacturing Ltd. (1992), 7 O.R. (3d) 779, 4 B.L.R. (2d) 108 (Gen. Div.); Onex Corp. v. Ball Corp. (1994), 12 B.L.R. (2d) 151 (Ont. Gen. Div.). 
conduct the arbitration, if any; (4) local procedural laws; (5) substantive laws of the agreement; (6) international conventions and treaties; and (7) international customary law.

The fundamental cornerstone of international arbitration is the agreement between the parties themselves. While the sanctity of private contract has traditionally been upheld by our courts, it is only recently that national law courts have begun to consistently recognize the importance of having parties to private international disputes keep their agreements to arbitrate.

As discussed by the United States Supreme Court in Mitsubishi Motor Corp. v. Soler Chrysler-Plymouth:

The expansion of American business and industry will hardly be encouraged if, notwithstanding solemn contracts, we insist on a parochial concept that all disputes must be resolved under our laws and in our courts... We cannot have trade and commerce in world markets and international waters exclusively on our own terms, governed by our laws, and resolved in our courts.?

The same attitude has been adopted and expressed by Canadian courts. Kerans J.A., in Kaverit Steel and Crane Ltd. v. Kone Corp. for example, held:

It is common ground that the evident purpose of Alberta's acceptance of the Convention is to promote international trade and commerce by the certainty that comes from a scheme of international arbitration. As Justice Potter Stewart said in Scherk v. Alberto-Culver (1974), 417 U.S. 506 (1974), at p. 516:

\footnotetext{
"...uncertainty will almost inevitably exist with respect to any contract touching two or more countries, each with its own substantive laws and conflict-of-laws rules. A contractual provision specifying in advance the forum in which disputes shall be litigated and the law to be applied is, therefore, an almost indispensable precondition to achievement of the orderliness and predictability essential to any international business transaction."
}

In modern times, the process of institutionalization began with the creation of certain international rules and bodies to arbitrate disputes between states. One of the first prominent institutions in this regard was the Permanent Court of Arbitration, established by the Hague Convention of 1899, the Convention for the Pacific Settlement of International Disputes. This was followed by the development of rules and procedures for the settlement of disputes arising between states and investors. This latter development can be attributed, in part, to the third world, or South's demands for a New International Economic Order (NIEO) throughout the 1960s and 1970s. The NIEO originally heralded five basic principles, two of which included sovereign equality and territorial integrity. These principles underscored the South's proclaimed right to control (1971). 
and develop their own natural resources. Many nations, particularly the oil-rich nations of the Middle East, began nationalizing western-based resource companies and disputes over appropriate compensation arose. These disputes, in turn, led to the development of mechanisms for their resolution.

The International Centre for the Settlement of Investment Disputes (ICSID) was established by the Washington Convention of 1965 under the auspices of the World Bank to deal with these and other investment disputes arising between a state and the nationals of another contracting state. Although the basic rules and procedures of ICSID follow the best principles of modern arbitration, the potential impingement of such procedures on the sovereignty of independent states has been modified by permitting an extraordinary form of challenge after the award. This process permits a party to move, in certain events, to interpret, revise or annul the award. Either the original tribunal or a fresh tribunal may hear the matter. In at least one case, an award was annulled in this manner.

As already noted, arbitration itself is not new. As we have progressed through the twentieth century, the institutional procedures to facilitate the resolution of international commercial disputes between private parties has gradually developed. Although rules, procedures and institutional bodies have been available for the resolution of private disputes for much of this century, it has only been within the last fifteen to twenty years that private parties have begun to make extensive use of available facilities. One of the oldest institutions for the settlement of private party disputes is the International Chamber of Commerce (ICC). This body was founded in 1919, with a Court of Arbitration established in 1923. More than half of the cases dealt with under the ICC have occurred in only the last fifteen years. ${ }^{9}$ Other notable institutions include the American Arbitration Association (AAA), the Inter-American Commercial Arbitration Commission (IACAC); the London Court of International Arbitration (LCIA); and more recently, the Stockholm Chamber of Commerce (SCC).

This process of institutionalization with respect to private dispute resolution has also included the creation and adoption by states of international conventions and treaties designed to facilitate the enforcement of arbitral awards and to limit the recourse of parties to judicial appeals in contracting states. The most well-known, and the one to date having the greatest impact on the growth of international commercial arbitration, is the New York Convention of 1958. The purpose of the Convention is to provide national courts with a uniform approach to enforcing arbitral awards by providing limited procedural grounds for which enforcement may be refused. Although ratification of the New York Convention is not quite universal, it has been quite successful - so much so that it can fairly be said that it is easier to enforce an arbitral award in a contracting state than it is to enforce a judicial award rendered in another state. ${ }^{10}$ Publications, Inc. 1990) at 4-5.

10 E.D. Wagoner, "Tailoring the ADR Clause in International Contracts" (1993) 48:2 Arb'n J. 77 at 80; H. Smit, "The Future of International Commercial Arbitration: A Single Transnational Institution?" (1986) 25 Col. J. Transnat'] L. 9 at 10. 
Other Conventions, both regional and otherwise, include the Montevideo Convention of 1889, the Geneva Protocol of 1923, the Geneva Convention of 1927, the European Convention of 1961, the Strasbourg Uniform Law of 1966, the Moscow Convention of 1972, the Panama Convention of 1975 and the Montevideo Convention of 1979. All these conventions, in one manner or another, share the common features of supporting submissions to arbitration as a means of resolving private international disputes and the enforcement of subsequent awards.

Institutionalism has also provided many advantages for ad hoc arbitrations, that is, those drawn up, conducted and administered by the parties themselves. The UNCITRAL Arbitration Rules" were adopted by the United Nations General Assembly in 1976 to "establish a procedural framework which, if properly adhered to, would ensure general international acceptance of the result of the arbitration, particularly under the New York Convention." ${ }^{12}$ These rules have attained world-wide significance and are often chosen for administration by agencies such as the ICC or the AAA. ${ }^{13}$ Canada and its provinces have been leaders in adopting and following the UNCITRAL Rules.

Conflict, of course, is inherent in the various layers of laws and rules that make up our system of international commercial arbitration. While the process of institutionalization has helped to buffer the consequences of conflicts that exist due to the parochial application and enforcement of national and local laws, the next step in this process is only recently underway. This is the unification of laws process. Since its inception in 1966, UNCITRAL has dedicated its efforts towards the harmonization and unification of the laws of international trade. The UNCITRAL Model Law on International Commercial Arbitration, ${ }^{14}$ adopted in 1985, represents the international community's efforts towards this next step - pursuing unification through the adoption by states of similar laws rather than through the conclusion of multilateral treaties and conventions. The purpose of the Model Law was expressed in the Report of the Secretary General of the United Nations, entitled Possible Features of a Model Law on International Commercial Arbitration:

The ultimate goal of a model law would be to facilitate international commercial arbitration and to ensure its proper functioning and recognition. Its practical value would, in particular, depend on the extent to which it provides answers to the manifold problems and difficulties encountered in practice. Thus, in preparing the model law an attempt should be made to meet the concerns which have repeatedly been expressed in recent years, sometimes even labelled as "defects" or "pitfalls" in international commercial arbitration.

UNCITRAL, UNCITRAL Arbitration Rules (New York: United Nations, 1977).

Redfern, Hunter \& Smith, supra note 2 at 480.

J.D. Franchini, "International Arbitration Under the UNCITRAL Arbitration Rules: A Contractual Provision for Improvement" (1994) 62 Ford. L. Rev. 2223 at 2227.

Supra note 4. 
A major complaint in this respect is that the expectations of parties as expressed in their agreements on arbitration procedure are often frustrated by conflicting mandatory provisions of the applicable law....15

A discussion of some of these conflicts, a more in-depth discussion of the unification process through the Model Law, and the Canadian experience with the Model Law and international commercial arbitration follow.

\section{B. INTERNATIONAL COMMERCIAL ARBITRATION DEFINED}

The conflicts inherent in the system reach the most fundamental of issues, and that is, what is international commercial arbitration? How can we talk about something unless we can define precisely what it is we are talking about? Instinctively, we might understand international commercial arbitration to be a system for the resolution of disputes between two parties from different jurisdictions who have entered into a commercial contract for the sale of goods (tangible or intangible) or services, who do not wish to submit their disagreements to a foreign judicial system that may not have the jurisdiction or desire to consider the international nature of the parties' contract. It seems simple enough. Unfortunately, it is not.

The term "international" cannot be understood without reference to a particular set of governing rules or laws. For example, under French law, an arbitration is international if the dispute is "international"; ${ }^{16}$ that is, the objects of the contract extend beyond national borders. Among the factors a court will consider are "the nationality of the parties, their place of business, the place of performance of the main contract, the place of arbitration, the applicable law, or the intervention of an international institution ... but none of them will be really determining when taken separately."17 Under Swiss law, an arbitration is international if at least one of the parties is not a national of nor resident in Switzerland; ${ }^{18}$ the nature of the dispute is irrelevant. An arbitration under Bulgarian law is likewise regarded as international if the domicile or the seat of at least one of the parties is in a foreign country. ${ }^{19}$ Under the Arbitration Rules of the International Chamber of Commerce (ICC), the nature of

UN Doc. ACN.9207, paras. 9-10 (14 May 1981).

Décret no. 81.500 du 12 mai 1981, J.0., 14 May 1981, Art. 1492 N.C. proc. civ: "C'est international l'arbitrage qui met en cause des interêts du commerce international" (Arbitration is international if it implicates international commercial interests).

17 Y. Derains, "France" in A. Van Den Berg \& P. Sanders, gen. eds., International Handbook on Commercial Arbitration (Deventer, The Netherlands: Kluwer Law and Taxation Publishers, 1984) at France-2 [hereinafter Int'l Handbook].

Swiss Private International Law Act, c. 12, art. 176(1), reprinted in Dr. R. Briner, "Switzerland" Int'l Handbook, ibid., vol. 3 at Switzerland: Annex II-1.

Law on International Commercial Arbitration, published in State Gazette No. 60 (5 August 1988), as amended by Law Amending the Law on International Commercial Arbitration, published in State Gazette No. 93 (2 November 1993): see the discussion of Z. Stalev, "Republic of Bulgaria" in Int'l Handbook, ibid., vol. 1 at Bulgaria-i. 
the dispute governs, ${ }^{20}$ whereas, under the European Convention of 1961, the nationality or place of residence of the parties is determinative. ${ }^{21}$

The term "commercial" suffers a similar problem. Article I(3) of the New York Convention contains a reservation that entitles a contracting party to determine whether or not a dispute is "commercial" and thus governed by the Convention. "Commercial," therefore, becomes defined by reference to national laws. An illustration of the problems this can cause is found in an arbitration proceeding brought before the High Court of Bombay in 1979. The High Court determined that the dispute was not "commercial," therefore, the New York Convention did not apply and the award could not be enforced under it:

In my opinion, in order to invoke the provisions of [the Convention], it is not enough to establish that an agreement is commercial. It must also be established that it is commercial by virtue of a provision of law or an operative legal principle in force in India. ${ }^{22}$

For the purposes of this paper, we have adopted the broad, all-inclusive definition of international commercial arbitration found in chapter I, article 1 of the UNCITRAL Model Law, and therefore referenced in the Alberta International Commercial Arbitration Act, S.A. 1986, c.I-6.6. This definition, set out below, provides that an arbitration will be defined as "international" if the parties are resident in different jurisdictions, the place of arbitration is situate outside of the residency of both parties, or the nature of the dispute is international.

(3) An arbitration is international if:

(a) the parties to an arbitration have, at the time of the conclusion of that agreement, their places of business in different States; or

(b) one of the following places is situated outside the State in which the parties have their place of business:

(i) the place of arbitration if determined in, or pursuant to, the arbitration agreement;

Article 1 of the "Rules for the ICC Court of Arbitration" in ICC, Guide to Arbitration (Paris: ICC, 1983) at 70, states that the Court of Arbitration shall "provide for settlement of arbitration of business disputes of an international character...." art. I.I(a) provides that the Convention applies to "arbitration agreements concluded for the purpose of settling disputes arising from international trade between physical or legal persons having, when concluding the agreement, their habitual place of residence or their seat in different Contracting States..."

Indian Organic Chemical Limited v. Chemtex Fibres Inc. (Parent Company) (U.S.) (1979), 4 Yrb'k Comm'l Arb. 271 at 273, and discussed in Redfern, Hunter \& Smith, supra note 2 at 460 . The decision of the High Court has not been followed in subsequent cases. 
(ii) any place where a substantial part of the obligations of the commercial relationship is to be performed or the place with which the subject-matter of the dispute is most closely connected; or

(c) the parties have expressly agreed that the subject-matter of the arbitration agreement relates to more than one country. ${ }^{23}$

The term "commercial" is understood under the Model Law according to the following model law commentary:

The term "commercial" should be given a wide interpretation so as to cover matters arising from all relationships of a commercial nature, whether contractual or not. Relationships of a commercial nature include, but are not limited to, the following transactions: any trade transaction for the supply or exchange of goods or services; distribution agreement; commercial representation or agency; factoring; leasing; construction of works; consulting; engineering; licensing; investment; financing; banking; insurance; exploitation agreement or concession; joint venture and other forms of industrial or business co-operation; carriage of goods or passengers by air, sea, rail or road. ${ }^{24}$

According to Dr. Aaron Broches, the Working Group drafting the Model Law generally agreed that the term "commercial" should be given a wide meaning. ${ }^{25}$ An early proposal to incorporate an illustrative list of types of "commercial" activities had been rejected on the grounds that this was contrary to the legislative techniques in a number of jurisdictions. The Working Group decided, therefore, to append a footnote to the text to provide states with a useful guideline for the interpretation of the term.

\section{THE PARADIGM: FREEDOM OF CONTRACT AND LEX ARBITRI}

The paradigm of our system of international commercial arbitration is comprised of potentially inherent conflicting principles: freedom of contract, party autonomy and lex arbitri.

\section{Freedom of Contract and Party Autonomy}

The first principles underlying the paradigm are the concepts of freedom of contract and party autonomy. The parties should be free to determine their rights and obligations under a contract, and they should be free to determine how to resolve disputes arising under it. In that respect, most parties choose the concept of "legal neutrality." One of the appealing features of international commercial arbitration for parties is the notion that each of their interests will be governed by the contract that they have agreed to and

UNCITRAL Model Law, supra note 4, art. 1(3). Note, however, art. 1(5) of the Model Law states that this definition shall not affect any other law of the State by virtue of which certain disputes may not be submitted to arbitration or may be submitted to arbitration only according to the provisions of the national law.

2s Dr. A. Broches, "Commentary on the UNCITRAL Model Law" in Int'l Handbook, ibid., vol. 4, Commentary UNCITRAL Model Law-1 at Commentary UNCITRAL Model Law-2. 
not subject to nationalistic favoritism under the other party's judicial system. "Knowledge and trust of the other party's judicial system are usually minimal. There are concerns about local bias, corruption, delays, procedural labyrinths requiring highpriced local legal guides, and the like." 26

Essentially, under the rubric of freedom of contract and party autonomy, the parties may select their own decision-makers who are specialists and knowledgeable about a particular industry or trade. They have, in addition: the ability to adopt procedures that will meet the needs of each case; the ability to choose which laws will govern which substantive aspects of a dispute; and where the arbitration will take place. And while increasingly less so, there is the added advantage of relative efficiency and speed in the resolution of the dispute. ${ }^{27}$

The institutionalization of international commercial arbitration through the creation of international arbitral institutions such as the ICC, the AAA, the LCIA and the SCC has provided parties with their choice of "ready-made" rules and procedures to govern the arbitration of their dispute. These institutions each provide parties with a set of procedural governing rules ${ }^{28}$ to determine how arbitrators will be selected, how many will be selected, whether they must be independent, how the place of arbitration will be selected (if the parties have failed to do so), whether the arbitrators can determine their own jurisdiction, the extent that parties must be given a full opportunity to be heard and present their case, the disclosure and production of documents, the ability to make interim orders, the availability of assistance from the courts, the right to crossexamine witnesses, the appointment and use of experts, the selection of the governing law (if the parties have failed to choose), whether the arbitrators must provide written reasons for their decision, the procedures for making a decision in the event of disagreement between the arbitrators, and the like.

Of the various arbitral institutions, the ICC has probably the widest acceptance. ${ }^{29}$ A recent example of this acceptance is the decision of the People's Republic of China in late 1994 to become a member of the ICC Court, thereby further overcoming its previous determined attachment to conducting arbitrations on the mainland. One of the features of ICC is the Court of Arbitration - which is not in fact a court, but an administrative and supervisory body. Before releasing an award, the Court of Arbitration must approve the arbitrator's award as to form and may lay down

P.E. Mason, "International Commercial Arbitration" (1994) 49:2 Dispute Res. J. 22 at 23.

For a discussion see J.G. Castel, A.L.C. de Mestral \& W.C. Graham, The Canadian Law and Practice of International Trade (Toronto: Emond Montgomery Publications Ltd., 1991) at 486.

A comparative chart of the provisions of the Alberta International Arbitration Act, S.A. 1986, I. 1-6.6; the ICC; the AAA; UNCITRAL Arbitration Rules, 1976; the LCIA; the International Bar Association Supplementary Rules (IBA); the CPR Institute for Dispute Resolution Model ADR Procedure; and the British Columbia International Commercial Arbitration Centre on twenty-five different points is found as an appendix to a paper by E.D.D. Tavender, Q.C., "Consideration of Fairness in the Context of International Commercial Arbitrations" (Paper presented to the Canadian Petroleum Law Foundation, 34th Annual Research Seminar in Oil \& Gas Law, 7-10 June 1995, Jasper, Alberta) [unpublished].

S.I. Ezer, International Exporting Agreements (New York: Matthew Bender \& Co., Inc., 1994) at 17-12. 
modifications or draw the arbitrator's attention to points of substance. The rationale for this role was succinctly outlined by Judge Johan Steyn in Bank Mellat v. GAA Development and Construction Company:

The supervisory function which is germane to the issues in the present case is the court's power of scrutiny of awards before they are published. That power exists, because the ICC system, the most truly international of all arbitral systems, provides for the conduct of arbitrations in most countries of the world, and the members of a three man tribunal frequently come from different continents, or at least from different countries, with fundamentally different legal systems. It is regarded as the first imperative of the ICC system that awards rendered under it should be enforceable.... The system of scrutiny of awards by the court contributes to the enforceability of ICC awards... The process of scrutiny is directed at the internal coherence and consistency of the award. But it may also sometimes reveal a procedural flaw which can be corrected....

The ICC has been the principal model for international arbitration. This influence has created some very useful techniques which have been followed by other institutions. Not all its innovations, however, are useful. Much criticism has been levelled at the procedure for outlining the issues to be decided by the arbitrator. Article 13(1) of the ICC Rules requires the parties to define the issues and draw up "Terms of Reference" at the outset of the arbitration. ${ }^{31}$ The benefits of this practice have been questioned, particularly by critics from common-law countries where the extensive use of "discovery and development of facts after the exchange of initial pleadings ... do not require an early definition of the issues by the parties." ${ }^{132}$ The effect of the Terms of Reference is to bind parties to the initial claims they have advanced. ${ }^{33}$

The AAA and the London Court of International Arbitration (LCIA) have both been mainstays of domestic arbitration since their inception. In recent years, both of these bodies have revised and modernized their rules. Both are becoming highly regarded institutions for international commercial arbitration. ${ }^{34}$ As both the AAA and the LCIA come from common law countries, there is greater scope for production of documents and discovery procedures by the parties if they choose to avail themselves of these procedures. $^{35}$

The Stockholm Chamber of Commerce (SCC) is perhaps the most widely used by the socialist countries. Most state contracts in China, for example, have traditionally specified that any arbitration will take place in China under the auspices of the China

[1988] 2 Lloyd's L. Rep. 44 (Q.B., Com. Ct.), and discussed in Craig, supra note 9 at 428, 471 . "Rules for the ICC Court of Arbitration," art. 13(1), in ICC, supra note 20 at 76.

Craig, supra note 9 at 253; see also Smit, supra note 10 at 26-27.

In ICC Case 3267/1984, excerpted in (1987) 12 Yrb'k Comm'l Arb. 87 at 91, discussed in Craig, ibid. at 255 , the arbitration tribunal held that it was beyond their authority and jurisdiction to decide upon subsequently identified issues.

See Ezer, supra note 29 at 17-14, 17-17.

It is noted by E.D. Wagoner, supra note 10 at 79 that the "extent to which discovery is allowed in an arbitration proceeding ... tends to reflect the attitude of courts toward discovery in litigation. European countries tend to allow very limited, if any discovery. U.S. courts often allow extensive pre-trial discovery..." 
International Economic and Trade Arbitration Commission (CIETAC). Increasingly, however, in recognition of the need to facilitate and encourage Sino-foreign trade, Chinese officials have been willing to accept arbitration in Sweden, under the SCC rules, as an alternative forum for the settlement of disputes. ${ }^{36}$ Now, with the People's Republic of China joining the Paris Court of the ICC, it remains to be seen whether the SCC can continue its prominence with Chinese disputes abroad.

The SCC was also, prior to the break up of the U.S.S.R., the favoured arbitration institution for commercial disputes in East-West trade. Notably, "the "US/USSR Optional Clause Agreement (1977),' ... set forth in letters between the [AAA] and the U.S.S.R. Chamber of Commerce, [specified that] the SCC Institute [was] designated the appointing authority and [that arbitration under SCC rules was] 'acceptable for inclusion in contracts' between [U.S.S.R. foreign trade organizations and U.S. nationals]. ${ }^{1.37}$

Many jurisdictions have set up smaller centres which have tended to be restricted to disputes arising between nationals of that jurisdiction and foreign parties. One of the most well-known is the China International Economic and Trade Arbitration Commission (CIETAC), which has ranked in the past as the second busiest international arbitration body in the world. ${ }^{38}$ Others include the Kuala Lumpur Regional Centre for Arbitration, the Cairo Regional Centre for Commercial Arbitration, the Netherlands Arbitration Institute, the Japan Commercial Arbitration Association, the Hong Kong Arbitration Centre, and in Canada, the British Columbia International Commercial Arbitration Centre and Le Centre d'arbitrage commercial national et international du Quebec.

These institutions, and other centres set up nationally to administer international commercial arbitrations, have done much to make arbitrations a fundamental part of international commercial transactions. In fact, today most international trade disputes are resolved by arbitration. ${ }^{39}$ In addition to the rules and procedures set out, the other important aspect is that most arbitral institutions provide trained staff, facilities and registries to ensure that the dispute is resolved expeditiously and efficiently. However, as is discussed below, the availability of institutions and the role they play in facilitating the resolution of disputes may be hampered or aided by conflicting or complimentary national and local laws. "Intemational Arbitration: The Alternative of the Stockholm Chamber of Commerce" (1988) 22 Int'l Lawyer 837 at 839.

38 Moser, supra note 36. Moser notes that the centre deals largely with disputes arising from importexport contracts, joint ventures and other investment disputes arising between Chinese nationals and foreign parties. 


\section{The Lex Arbitri}

As discussed, the principles of freedom of contract and party autonomy may be circumscribed by the variants of national and local laws in the country where the arbitration will take place - the lex arbitri. When these laws conflict with the rules and procedures adopted by the parties, with international conventions or treaties, international customary law and the like, the laws of the forum may take precedence. Indeed, the lex arbitri has the potential to extend to a number of matters affecting the rights and obligations of the parties under contract and under arbitration, including:

- arbitrability;

- the validity of the arbitration agreement;

- the jurisdiction of the arbitrators;

- the appointment, removal and replacement of arbitrators;

- challenge of arbitrators;

- time limits;

- the conduct of the arbitration, including possible rules for the disclosure of documents (discovery);

- interim measures of protection;

- whether there is power to consolidate arbitrations;

- whether the arbitral tribunal is able to decide ex aequo et bono;

- the form and validity of the arbitral award; ...

- the finality of the award (including any rights of recourse against it under national law) ${ }^{40}$; and

- costs.

The lex arbitri, of course, is most relevant where the parties have failed to specify in the contract the rules under which the arbitration will proceed. However, even if parties have made the appropriate choice, the lex arbitri can have significant implications for the conduct of the proceedings. The selection of the place where the arbitration will take place, therefore, is highly significant.

Even when parties have agreed that the case is to be conducted under established arbitration rules or contract provisions, the local law will control matters not covered by the rules or contract, also local law will govern to the extent that the rules or contract conflict with those provisions of the law of the place of arbitration which parties are not free to waive or vary by contract - often called mandatory, imperative, or nonexcludable provisions of law. Thus, for example, if a contract provides that arbitration will take place in the country of one of the parties and if the law of that country contains a mandatory provision which forbids foreigners to act as arbitrators, that local law would supersede provisions of rules - such as the AAA, UNCITRAL, or ICC rules - which call for the arbitrator to be from a third country.1

H.M. Holtzmann, "The Importance of Choosing the Right Place to Arbitrate an International Case" in L.F. Brown, ed., The International Arbitration Kit, 3d ed. (New York: American Arbitration Association, 1986) 119 at 129. 
An example of this is found under article 33(e) of the Swiss Concordat, ${ }^{42}$ which states that awards that do not set out, in writing, the factual, legal and equitable basis for a decision may be declared null and void by a cantonal court. It is noteworthy, then, that written reasons are not mandatory under the AAA, ${ }^{43}$ the UNCITRAL Arbitration Rules $1976,{ }^{44}$ and the LCIA. ${ }^{45}$ The case of Scherk v. Alberto-Culver Co ${ }^{46}$ is also illustrative. In that case a U.S. federal district court held that a dispute involving the interpretation of U.S. securities law was non-arbitrable under U.S. law and could not be the subject of arbitration proceedings between the parties. Fortunately, the Supreme Court reversed this decision, holding that respect for the parties' choice of forum and choice of law were an "almost indispensable precondition to achievement of the orderliness and predictability essential to any international business transaction." 47

National arbitration Acts usually deal with the issue of arbitrability. Typically, most Acts provide that all matters are arbitrable which can be submitted to compromise and settlement, or which involve subject-matter the parties are free to dispose of. ${ }^{48}$ Some arbitral clauses employ the language of "disputes arising from" certain agreements which may even include torts committed between those parties. ${ }^{49}$ On the other hand, in most countries, whether by direct exclusion, or according to public policy, matters relating to the validity of patents or trademarks and anti-trust and bankruptcy law may not be the subject of arbitration. ${ }^{50}$ Interestingly, in Bulgaria, ${ }^{51}$ Israel, $^{52}$ and

InterCantonal Arbitration Convention (Concordat) (27 March/29 August 1969), text reproduced in Int'l Handbook, supra note 17, vol. 3 at Switzerland: Annex I-1.

"American Arbitration Association International Arbitration Rules," text reproduced in (1992) 17 Yearb'k Comm'l Arb. 310 at 319, art. 28(2). Under art. 28.2 the parties can agree that the arbitrator need not give reasons, and reasons are not required if the award is the result of a settlement under art. 30(1). UNCITRAL Arbitration Rules, supra note 11, arts. 32(3), 34(1).

"Rules of London Court of International Arbitration," text reproduced in (1985) 10 Yearb'k Comm'l Arb. 157 at 163, art. 16(1).

417 U.S. 506 (1974), and discussed in Redfern, supra note 2 at 441.

Ibid. at 516.

See e.g. National Code of Civil and Commercial Procedure, art. 737, Law 17.454 (19 September 1967) as reformed by Law 22.434 (16 March 1981), text consolidated according to Decree 1.042 of 1981 (Unofficial Translation) (Argentina); Judicial Code, Sixth Part: Arbitration, art. 1676 (adopted 4 July 1972 and amended 27 March 1985) (Belgium); Arbitration Law, 5728 - 1968, as amended by the Arbitration (Amendment) Law 5734-1974, s. 2 (Israel); Arbitration Act (1 December 1986) Code of Civil Procedure, Book Four, Title One: Arbitration in the Netherlands, art. 1020(3) (Netherlands); The Arbitration Act of 1929, Lag om skiljeman, 1929 No. 145, s. 1 (Sweden). The texts of these laws can be found in Volumes 1-4 of Int'l Handbook, supra note 17. Kaverit Steel, supra note 5, discussed infra.

so See e.g. National Code of Civil and Commercial Procedure (Argentina) in Int'l Handbook, supra note 17, vol. 1 at Argentina: Annex I-1, and discussion by Prof. H.A. Grigeria Naon, ibid. at Argentina-9; but see Code of Civil Procedure, Law No. 5869 (11 January 1973) (Brazil), ibid. at Brazil: Annex II-1 and the discussion of Prof. V. Rangel, ibid. at Brazil-6, regarding patents and trademarks.

Law on International Commercial Arbitration, published in State Gazette No. 60 (5 August 1988), as amended by Law Amending the Law on International Commercial Arbitration, published in State Gazette No. 93 (2 November 1993), art. 2, referring to immoveables wherever situate, text set out in Int'l Handbook, ibid, vol. 1 at Bulgaria: Annex I-1. 
Turkey, ${ }^{53}$ disputes concerning proprietary rights in immoveables may not be the subject of arbitration. In Australia, any arbitration agreement in a bill of lading or similar document relating to the international carriage of goods to or from any port in Australia will be declared void under the Sea-Carriage of Goods Act. ${ }^{54}$

The Alberta Court of Appeal, in Kaverit Steel, ${ }^{55}$ recently interpreted a submission agreement that provided that "disputes 'arising out of or in connection with' the contract"s6 were to be arbitrated. The Court held that if the claim in question relies on the existence of a contract between the parties, it should go to arbitration. The Court stated:

In my view, this submission extends beyond rights and duties created by the contract. A dispute meets the test set by the submission if either claimant or defendant relies on the existence of a contractual obligation as a necessary element to create the claim, or to defeat it. Thus, the pleading here that relies upon a claim of a conspiracy by unlawful means to harm the distributor meets the test. This is because the breach of the contract is relied upon as the source of the "unlawfulness." That dispute should be referred to arbitration.

I cannot say that a dispute arises out of or in connection with a contract unless the existence of the contract is germane to either the claim or the defence. It is not enough to say that the events that give rise to the claim also give rise to a claim for breach of contract. One must be able to say that the other claim relies on the existence of the contractual obligation. ${ }^{57}$

The Court was not convinced that the prospect of "inconveniently overlapping litigation and ... conflicting decisions" warranted a refusal to refer anything to arbitration. ${ }^{58}$

In the past, English courts were criticized for their highly interventionist attitudes towards the review of arbitral awards. In one case, Dalmia Dairy Industries Ltd. v. National Bank of Pakistan, ${ }^{59}$ the English Court of Appeal held that under English and Indian law, the arbitrator could not determine his own jurisdiction. As this had occurred in the arbitration proceedings between the parties, the award was not enforced by the English courts. Under most rules, the arbitrators are given the authority to decide their own jurisdiction so that the proceedings can continue unimpeded by court applications, subject, of course, to judicial review after an award has been granted. Fortunately, in

As discussed by Prof. R. Koral, "Turkey" in Int'l Handbook, ibid., vol. 4 at Turkey-10.

International Arbitration Act 1974, art. 2C, text reprinted in Int'l Handbook, ibid., vol. 1 at Australia: Annex II-1.

Supra note 5.

Ibid. at 350.

Ibid. at 351-52.

Ibid. at 348. Kerans J.A. stated: "I am of the view that the applicable provisions of the International Commercial Arbitration Act under review do not permit that approach ... the statute commands that what may go to arbitration shall go. No convenience test limits references." (ibid.) [emphasis in original].

[1978] 2 Lloyd's L. Rep. 223 (C.A.). 
1979 the law was amended and the ability of parties to submit questions of law as of right to the courts for determination in the middle of an arbitration was abolished. ${ }^{60}$ Now, pursuant to s. 1(2) and (4) of the 1979 Act, following the proceedings, parties must have leave of the court to appeal on the basis that "the determination of the question of law concerned could substantially affect the rights of the parties." Commentators have suggested that the English courts have laid down stringent requirements for granting leave to appeal. "It is, for example, extremely difficult to obtain leave to appeal on questions of contractual interpretation, unless it involves a standard form contract affecting many disputes." ${ }^{161}$ In many countries, no appeal lies to the courts from an arbitration proceeding. ${ }^{62}$

A recent decision of the House of Lords, however, has caused some commentators to suggest that the interventionist attitudes of English courts have not been put to rest. In Coppée-Lavalin S.A./N.V. v. Ken-Ren Chemicals and Fertilizers Limited, ${ }^{63}$ the highest court of England determined that Ken-Ren Chemicals had to provide security for costs in the arbitration proceedings and that the arbitration proceedings would be stayed until Ken-Ren had paid the security. Lord Mustill, dissenting in the result, reasoned that security for costs should not be awarded, on the basis that the freedom of the parties to choose a method of private dispute resolution should be respected. He stated:

My Lords, there is plainly a tension here. On the one hand the concept of arbitration as a consensual process, reinforced by the ideal of transnationalism, leans always against the involvement of the mechanisms of state through the medium of a municipal court. On the other side there is the plain fact, palatable or not, that it is only a court possessing coercive powers which can rescue the arbitration if it is in danger of foundering... Total consistency cannot be expected. Each domestic court has its own practical methods ... The result is a considerable diversity from one country to another....6

This was effected by amendment under the English Arbitration Act of 1979. See W.W. Park, "Judicial Supervision of Transnational Commercial Arbitration Law: The English Arbitration Act of 1979" (1980) 21 Harv. Int. L.J. 87.

Sir J. Steyn \& V.V. Veeder Q.C., "England" in Int'l Handbook, supra note 17, vol. 2 at England-37, citing in support: Pioneer Shipping LId. v. BTP Tioxide, [1982] A.C. 724 (H.L.); Antaios Compania Naviera S.A. v. Salen Rederierna A.B., [1985] A.C. 191 (H.L.); and Aden Refinery Co. Ltd. v. Ugland Management Co. Ltd., [1986] 2 Lloyd's L. Rep. 336 (C.A.). For example, in China, arbitration awards are final and appeals are not allowed, even if the arbitration agreement so provides: see the discussion by Prof. T. Houzhi, "The People's Republic of China" in Int'l Handbook, ibid., vol. 1 at China, P.R.-13. See also the discussion of T. Oyekunle, "Federal Republic of Nigeria" in Int'l Handbook, ibid., vol. 3 at Fed. Rep. of Nigeria-20, although there is a limited right of appeal on a question of law. In Portugal, no appeal is allowed in international arbitration, unless the parties have agreed to this possibility in their arbitration agreement: as discussed by F. Cruz \& D.M. Vicente, "Portugal" in Int'l Handbook, ibid., vol. 3 at Portugal-15. 
The parties choose arbitration for better or worse. They relish the better features, of which there are many. When things take a turn for the worse there are limits beyond which they cannot be allowed, consistently with their arbitration agreement, to run to the courts for help. ${ }^{65}$

Parties should be aware when specifying that an arbitration will proceed in South Africa, that according to South African law, their courts have broad powers to rule on the binding effect of an arbitration agreement. Section 3 of the Arbitration Act 1965, ${ }^{66}$ provides that a court may set aside an arbitration agreement, or order that a particular dispute may not be referred to arbitration if the applicant can "on good cause" show why the dispute should not be referred to arbitration. It is believed that this power would be used judiciously.

In brief, the lex arbitri can have significant implications, potentially circumscribing the principles of freedom of contract and party autonomy. It is very important when choosing a forum to be familiar with the laws of the forum to determine whether or not the environment is hospitable to freedom of contract and party autonomy in international commercial arbitration.

\section{THE PROCESS OF UNIFICATION - THE NEXT STEP}

While the institutionalization process has clearly helped to generate movement towards the harmonization of national laws respecting international commercial arbitration, problems remain. These problems could be significantly ameliorated if states adopted substantially similar arbitration laws. This process is often referred to as the process of unification of laws. The unification process in international commercial arbitration has been at the forefront of the work of the United Nations Commission on International Trade Law (UNCITRAL). UNCITRAL, for example, has dedicated its efforts to promoting the ratification by states of the New York Convention.

Nonetheless, in 1977, a representative of the Asian-African Legal Consultative Committee requested a review of the operation of the New York Convention, noting the lack of uniformity in the approach of national courts to the enforcement of awards. The request was taken up by the Secretary General of UNCITRAL; however, the Secretary General concluded that a different approach to the uniform enforcement of arbitration awards was warranted. In a document entitled Study on the Application and Interpretation of the Convention on the Recognition and Enforcement of Foreign Arbitral Awards, ${ }^{67}$ the Secretary General concluded that the "harmonisation of the enforcement practices of states, and the judicial control of arbitral procedure, could be achieved more effectively by the promulgation of a model or uniform law ... [A] model 
law was more likely to lead to a realistic degree of harmonisation in practice than the less flexible approach of a convention or uniform law. ${ }^{168}$

The Model Law was adopted by UNCITRAL and open for ratification by states in 1985. One commentator has provided the following assessment:

The model law process, in general, involves the creation of uniform rules to eliminate local peculiarities which make international consistency impossible in certain areas of law.... The Model Law, with its eight chapters and thirty-six articles, is a comprehensive work governing the arbitration agreement, the composition and jurisdiction of the arbitral tribunal, the conduct of the arbitral proceedings, and the making of and recourse against the award ... UNCITRAL included in the Model Law an enforcement mechanism almost identical to that of the [New York Convention 1958]. ${ }^{69}$

The objectives of the Model Law include:

- the liberalization of international commercial arbitration by limiting the role of national courts, and by giving effect to the doctrine of "autonomy of the will," allowing the parties freedom to choose how their disputes should be determined;

- the establishment of a certain defined core of mandatory provisions to ensure fairness and due process;

- the provision of a framework for the conduct of international commercial arbitrations, so that in the event of the parties being unable to agree on procedural matters the arbitration would nevertheless be capable of being completed; and

- the establishment of other provisions to aid the enforceability of awards and to clarify certain controversial practice issues. ${ }^{70}$

Two aspects of the Model Law approach have been cited as particularly appealing to states who have failed to ratify the New York Convention:

[First] it is not conceived as a treaty, and may therefore be adopted by national legislatures with whatever incidental wrinkles they require; the cumbersome process of ratification of international instruments is obviated[;] and

Redfern, Hunter \& Smith, supra note 2 at 508-09, paraphrasing the Secretary General's Report, ibid. A discussion of the creation and negotiation of the Model Law, written by an individual involved in the preparatory work is Broches, supra note 25.

K.T. Ungar, "The Enforcement of Arbitral Awards Under UNCITRAL's Model Law on Intemational Commercial Arbitration" (1987) 25 Col. J. Trans'I L. 717 at 719. The chapters of the Model Law are entitled: General Provisions; Arbitration Agreement; Composition of Arbitral Tribunal; Jurisdiction of Arbitral Tribunal; Conduct of Arbitral Proceedings; Making of an Award and Termination of Proceedings; Recourse Against Award; and Recognition and Enforcement of Award. 
[Second] its scope is limited to disputes relating to international contracts, thus leaving national legal systems the option to retain their traditional regime for purely domestic arbitrations." Law.

Canada, together with its provinces, was one of the first countries to adopt the Model

\section{E. NORTH AMERICAN FREE TRADE AGREEMENT}

Article 2022 of NAFTA is entitled "Alternative Dispute Resolution." The first paragraph of this article indicates that each of Canada, Mexico and the United States: "shall, to the maximum extent possible, encourage and facilitate the use of arbitration and other means of alternative dispute resolution for the settlement of international commercial disputes between private parties in the free trade area." 72

The article refers to appropriate procedures to ensure observance of agreements to arbitrate for the recognition and enforcement of arbitral awards and article 2022(4) provides that the Commission, which is the cabinet level body of NAFTA made up of the three foreign trade ministers of the parties,

shall establish an Advisory Committee on Private Commercial Disputes comprising persons with expertise or experience in the resolution of private international commercial disputes. The Committee shall report and provide recommendations to the Commission on general issues referred to it by the Commission respecting the availability, use and effectiveness of arbitration and other procedures for the resolution of such disputes in the free trade area.

This Advisory Committee has now been established with each of Canada, Mexico and the United States having ten serving members, two of whom are government officials, eight being selected from outside of the government. The first meeting was held in Mexico City on November 14, 1994, and the second meeting was held in Vancouver on June 19, 20 and 21, 1995. Thus far, the Committee has been broken into several subcommittees with a view to compiling information and criteria for the examination of existing laws, regulations and practices for non-judicial settlement of disputes, including the existence of specialized regimes within specific business sectors; to consider means for promoting the use of arbitration; and other procedures for resolving private international commercial disputes in the NAFTA area. There is also a further subcommittee created to fully examine the question of enforcement of arbitration agreements and awards.

It is believed that article 2022 in NAFTA is unique in international trade agreements and represents a potentially significant opportunity for business and arbitration practitioners alike to move quickly to establish a suitable infrastructure for the settlement of private disputes. It remains to be seen, of course, whether the Commission

$7 \quad$ Craig, supra note 9 at 460 [emphasis in original]; see also Ungar, supra note 69.

72 North American Free Trade Agreement between the Government of Canada, the Government of the United Mexican States and the Government of the United States of America (Ottawa: Minister of Supply and Services Canada, 1992), art. 2022(1). 
in due course will be persuaded to foster a more formal regime than merely the encouragement and facilitating of arbitration and other means of alternative dispute resolution. For the time being, a potentially significant first step towards this laudable objective has been taken with the implementation of this article. As the growth of trade within NAFTA develops and especially if additional parties, such as Chile, are added to the NAFTA Agreement, it is obvious that the need for well-known, reliable, userfriendly dispute resolution procedures will increase.

\section{THE CANADIAN EXPERIENCE}

\section{A. CANADA'S INDUCTION INTO THE MODERN WORLD OF INTERNATIONAL COMMERCIAL ARBITRATION}

Despite the fact that Canada has long been dependent upon the export of goods and services, ${ }^{73}$ the Canadian experience with international commercial arbitration is of relatively recent origin. Prior to 1986 , Canada's primary source of alternative dispute resolution legislation was the English Arbitration Act, 1889, ${ }^{74}$ and some rather limited federal legislation which made reference to arbitration, but which failed to distinguish between domestic arbitration and international arbitration. The change, when it came, was swift and far-reaching. In 1986, the federal and provincial governments implemented the New York Convention and passed the United Nations Foreign Arbitral Awards Convention Act. ${ }^{75}$ Shortly thereafter, both the federal government and the ten provinces and two territories enacted legislation based on the UNCITRAL Model Law. ${ }^{76}$ According to Professor William C. Graham:

the impetus for these dramatic changes has come from without rather than within, inspired by a perceived requirement that Canada's position as a nation highly depends on international trade and could no longer afford to be out of the mainstream of developments in intemational commercial arbitration. ${ }^{n}$

The push for change came largely as a result of the efforts of Brian R.D. Smith, Q.C. and John Crosby, Q.C., then the attorneys general of British Columbia and Canada

Approximately one-third of Canada's gross national product is generated by the export of goods and services: J.G. Castel, "International Commercial Arbitration" in D.P. Emond, ed., Commercial Dispute Resolution: Alternatives to Litigation (Aurora: Canada Law Book Inc., 1989) 121 at 122. (U.K.), 52 \& 53 Vict, c. 49.

75 R.S.C. 1985, (2d Supp.), c. 16. It has been suggested that Canada's late accession to the New York Convention was a consequence of the fact that Canada's two main trading partners, the United States, and the United Kingdom, did not accede to the Convention until 1970 and 1975 respectively. In addition, following the Privy Council's decision in the Labour Conventions case (Can. (A.-G.) v. Ont. (A.-G.), [1937] 1 D.L.R. 673), the federal government's authority to implement the New York Convention across Canada was uncertain at best.

For a complete list of the federal and provincial legislation and dates of enactment see W.C. Graham, "The Internationalization of Commercial Arbitration in Canada: A Preliminary Reaction" (1987-88) 13 Can. Bus. L.J. 2 at 6 n. For a comprehensive review of some of the modifications to the Model Law enacted by the provinces, see the Report of the Canadian Sub-Committee of NAFTA, Sch. B. (June 1995) [unpublished]. 
respectively. Both individuals had visions of promoting Vancouver as a Pacific centre for international arbitration, and the British Columbia International Commercial Arbitration Centre (BCICAC) was set up in 1986 to that end. ${ }^{78}$ As one of the first countries to enact legislation based on the Model Law, Canada quickly went from being twenty five years behind the times to being a world leader.

\title{
B. THE JUDICIARY'S RESPONSE: CREATING A FAVOURABLE ENVIRONMENT FOR THE SETTLEMENT OF INTERNATIONAL COMMERCIAL TRADE DISPUTES
}

\section{Enforcement of Foreign Arbitral Awards Under the Model Law}

The small body of law that has developed around the interpretation of the new legal regime in Canada shows that the Canadian courts have been ready to promote the spirit of internationalism and embrace the objectives of limited control and interference by the courts. The first indications of this shift in judicial attitude came from the British Columbia courts. The British Columbia Court of Appeal, affirming the decision of Esson C.J.S.C. in Quintette Coal v. Nippon Steel Ltd., ${ }^{79}$ fairly summarized the new public policy for the enforcement of foreign arbitral awards in Canada:

\begin{abstract}
We are advised that this is the first case under the British Columbia Act in which a party to an international commercial arbitration seeks to set the award aside. It is important to parties to future such arbitrations and to the integrity of the process itself that the court express its views on the degree of deference to be accorded to the decision of arbitrators. The reasons advanced in the cases discussed above for restraint in the exercise of judicial review are highly persuasive. The "concerns in international comity, respect for the capacities of foreign and transnational tribunals, and sensitivity to the need of the international commercial system for predictability in the resolution of disputes" spoken of by Blackman J. [in Mitsubishi Motors Corporation v. Soler Chrysler-Plymouth Inc., supra note 7] are as compelling in this jurisdiction as they are in the United States or elsewhere. It is meet therefore as a matter of public policy, to adopt a standard which seeks to preserve the autonomy of the forum selected by the parties and to minimize judicial intervention when reviewing international commercial awards in British Columbia. That is the standard to be followed in this case. ${ }^{80}$
\end{abstract}

At one time, Canadian courts were reluctant to give effect to submissions to international arbitral proceedings, as to do so would be contrary to public policy. Today, judicial thinking has shifted to such a degree that it is considered contrary to public policy not to give effect to arbitral submissions and to enforce a foreign arbitral award except on the very limited grounds found in ss. 35 and 36 of the Model Law. ${ }^{81}$

See C.O.D. Branson, "A View From the Centre" (1994) 52 Advocate 705.

Supra note 5.

Ibid. at 217 (C.A.) [cited to B.C.L.R.].

Article 36 of the Model Law, supra note 4, holds that judicial review of an arbitral award is limited to the following grounds: (a) incapacity; (b) invalidity of the arbitration agreement; (c) improper notice of the appointment of an arbitrator or of the proceedings or a party was otherwise unable to present its case; (d) the award deals with a matter not contemplated by the arbitration agreement; (e) the composition of the arbitral tribunal or the procedure did not accord with the arbitration agreement; (f) the award is not yet binding or has been set aside by a competent 
In M.A. Industries Inc. v. Maritime Battery Ltd., ${ }^{82}$ Stevenson J. of the New Brunswick Court of Queen's Bench similarly adopted a liberal and purposive approach to the application of the Model Law in the enforcement of an arbitral award. The respondents in that case argued that the award should not be enforced because the arbitrator did not take the oath prescribed by s. 10 of the New Brunswick Arbitration Act. The Court was not impressed with this parochial understanding of the reach of domestic legislation in an international case, holding that:

[s]ection 10 only applies to arbitrations in New Brunswick. If the respondent's argument were to prevail it would mean that an arbitrator would have to comply with the procedural requirements of every jurisdiction to which the parties might potentially look for enforcement. ${ }^{83}$

Ontario courts are taking a similar approach. In Schreter v. Gasmac Inc. ${ }^{84}$ Feldman J. concluded that the law did not give him the jurisdiction to refuse to enforce an award which had been given in Georgia and confirmed by the U.S. Federal Court, where the arbitrator failed to give reasons for her decision. Feldman J. outlined the court's jurisdiction and discretion under the Model Law:

The Model Law applies to international commercial arbitrations conducted in Ontario or elsewhere, but the only articles which apply to arbitrations conducted outside Ontario are arts. 35 and 36 ....

The applicant has complied with art. 35(2). Therefore the court shall enforce the award which shall be recognized as binding unless the court exercises its discretion based on one of the grounds set out in art. 36. The onus is on the respondent under art. 36(1)(a) to prove that one of the grounds exists for the court to exercise its discretion to refuse to recognize or enforce the arbitral award. Even then, the court is not obliged to refuse recognition of the award. Alternatively, under art. 36(1)(b) there is no onus of proof on the respondent to prove that the award is contrary to the public policy of Ontario, but if the court so finds, it still retains discretion to recognize an award even in such a case. ${ }^{85}$

The respondents also suggested and the court flatly rejected the argument that the public policy of Ontario should be "broadly construed when a court is reviewing a foreign arbitral award ... and that [the] court should be prepared to look more closely at the merits underlying the award decision...." ${ }^{86}$ The court held that the public policy exception must be narrowly construed, relying on the dicta of the courts in Quintette Coal. Feldman J. put it squarely to the respondents:

authority under the law of which the award was made; $(\mathrm{g})$ the subject-matter of the difference is not capable of settlement by arbitration under the law of the jurisdiction where the award is sought to be enforced; and (h) the recognition or enforcement of the award would be contrary to the public policy of the jurisdiction where the award is being enforced.

(1991), 296 A.P.R. 127 (N.B.Q.B.), aff d (1991), 310 A.P.R. 305 (C.A.).

lbid. at 136 (Q.B.) [emphasis added].

(1992), 89 D.L.R. (4th) 365 (Ont. Gen. Div.).

Ibid. at 370-71 [emphasis added only to the third emphasized phrase]. Article 35(2) states: "The party relying on an award or applying for its enforcement shall supply the duly authenticated original award or a duly certified copy thereof, and the original arbitration agreement referred to in article 7 or a duly certified copy thereof..." (supra note 4, art. 4). Schreter, ibid. at 377. 
if this court were to endorse the view that it should reopen the merits of an arbitral decision on legal issues decided in accordance with the law of a foreign jurisdiction and where there has been no misconduct, under the guise of ensuring conformity with the public policy of this province, the enforcement procedure of the Model Law could be brought into disrepute. ${ }^{87}$

Of particular interest is how the Court dealt with the argument that the award included a sum which amounted to an acceleration of future damages, thus being contrary to the public policy of Ontario. The court looked not to public policy on local matters, but to public policy on an international level. ${ }^{88}$ As noted by Branson, in light of this case, Quintette Coal, and the subsequent decision by the Ontario Court of Appeal, Boardwalk Regency Corp. v. Maalouf: ${ }^{89}$

[I]t can be said with reasonable certainty that Canadian courts have adopted a broad liberal approach to the recognition and enforcement of foreign arbitral awards, emphasizing the international aspects of the Model Law. ${ }^{90}$

In sum, Canadian courts are prepared to apply the enforcement provisions of the Model Law in a liberal, purposive and international manner.

\section{Giving Effect to the Arbitration Submission Agreement}

Another area in which Canadian courts have shown their willingness to emphasize the international aspects of the Model Law is through the stay of judicial proceedings. Although the courts have had few opportunities to interpret the new legislation, the trend in the case law is to emphasize the international aspects of the case and respect the wishes of the parties to arbitrate.

In BWV Investments Ltd. v. Saskferco Products Inc., ${ }^{91}$ the Saskatchewan Court of Appeal dealt with an application under the International Commercial Arbitration Act, ${ }^{92}$ (the "ICAA (Sask.)") for the first time. The lower court had concluded that, under the provincial Builder's Lien Act, ${ }^{93}$ (the "BLA") and the ICC Rules, the agreement to arbitrate was void and unenforceable. The chambers judge reasoned:

The BLA recognizes the interests of the other lien holders in this kind of situation and specifically provides protection for them. In my view, the effect of the arbitration agreement and the terms of the Rules of Arbitration of the International Chamber of Commerce is to make many of the provisions of the BLA inapplicable and therefore void under both s. 99(1) of the BLA and Article 8(1) of the Model Law."

Ibid. at 379.

Branson, supra note 78 at 707.

(1992), 6 O.R. (3d) 737.

Branson, supra note 78 at 707 .

Supra note 5.

S.S. $1988-89$, c. $1-10.2$.

S.S. $1984-85-86$, c. B-7.1

(1993), 108 Sask. R. 280 at 288 [emphasis in original]. 
The Court of Appeal disagreed, taking a broader view of the issues before it, holding:

Disputes in construction matters have generally been resolved through builders' lien legislation, and there may be a temptation to seek refuge in the familiar when faced with alternatives that have not yet been tested in this province. Nevertheless, the legislative scheme for international commercial arbitration exists to be used and, by express agreement, the principal parties in this appeal have invoked this new alternative. ${ }^{95}$

The court concluded that the submission agreement was not inconsistent with the "true" purpose of the BLA. The BLA did not "occupy the field" and the other systems of law could operate compatibly with the BLA without jeopardizing the rights of the third parties. Gerwing J.A. stayed the third-party actions until the arbitration was complete on the basis that article 8(1) of the ICAA (Sask.) was mandatory: "a court 'shall' refer disputes to arbitration...."196 He concluded that the role of the court was to apply the law in a manner that would uphold the objectives of the Model Law. ${ }^{97}$ To do otherwise would violate the strong public policy of international commercial arbitration.

This was the approach that had been taken by the Alberta Court of Appeal in Kaverit Steel. ${ }^{98}$ There, the Court rejected the argument that the existence of additional parties not subject to the submission agreement was a ground upon which a stay of judicial proceedings would be granted. By so ruling, the Court of Appeal of Alberta significantly circumscribed the discretion to grant or withhold a stay of judicial proceedings pursuant to the ICAA:

The power to grant or withhold a reference under the [ICAA (Alberta), S.A. 1986, c. I-6.6] is very limited, and the statute does not permit a decision on the test invoked by the leamed chambers judge, which resembles the forum conveniens test. For the purpose of argument, I accept the possibility (albeit I suspect very slim) of two suits at the same time, and even contradictory findings. Nevertheless, that is the method chosen by the parties. The [ICAA (Alberta)] directs me to hold them to their bargain. ${ }^{99}$

Kaverit Steel was cited with approval in Nanisivik Mines Ltd. v. F.C.R.S. Shipping $L t d^{100}$ where the Federal Court of Appeal held that if the requirements of article 8 of the Model Law are met, then a court must refer the matter to arbitration. As in Kaverit Steel, the Court noted that the presence of additional parties will exist in almost every lawsuit. As one commentator observed, if this was a basis for dismissing a submission to arbitration, the "ingenuity of counsel could subvert almost any agreement to arbitrate."101

BWV Investments Lid., supra note 5 at 9-10.

Ibid. at 17.

lbid. at 16.

Supra note 5.

Ibid. at 353.

(1994), 113 D.L.R. (4th) 536 (F.C.A.).

W.H. Hurlburt, "A Note on Escape from Arbitration Clauses: Effect of the New Arbitration Act" (1992) 30 Alta L. Rev. 1361 at 1373. 
While Canadian courts have upheld the objectives of the Model Law when dealing with the existence of additional parties and arbitrability, they have yet to deal with the issue of when in the court proceedings a stay will be granted. At common law, once a statement of defence is submitted, the defendant has attorned to the jurisdiction of the courts. ${ }^{102}$ Under the Model Law, the request to stay the proceedings must be made "not later than when submitting [the] first statement on the substance of the dispute"103 or in "an exchange of statements of claim and defence in which the existence of an agreement is alleged by one party and not denied by another..." 104 indicating quite clearly that the stay may be sought even after filing a defence. Accordingly, a potential conflict arises between Canada's domestic law and the Model Law and the New York Convention. ${ }^{105}$

The New York Convention provides that when the court is "seized of an action" and "at the request of one of the parties" it shall refer to matter to arbitration. ${ }^{106}$ It does not state specifically when that request must be made, or when, if ever, it is too late to point to a submission to arbitrate. This question remains unanswered. Arguably, in light of the willingness of Canadian courts to uphold the spirit and purpose of these provisions and the emphasis placed on the international context, they would likely overrule the common law rule of attornment to the extent to which a party can show it would suffer prejudice should the stay be granted.

\section{CONCLUSION}

Canada's economic well-being has been largely dependent on international trade. This dependency has increased as we approach the end of this century. More than ever before, Canadian businesses are looking abroad for opportunities to ply their trades and sell their expertise.

British American Oil Co. v. Born Engineering (1964), 44 D.L.R. (2d) 569 (Alta S.C.A.D.); Emanuel v. Symon, [1908] 1 K.B. 302 (C.A.); Richardson v. Allen (1916), 28 D.L.R. 134 (Alta. S.C.A.D.); Roglass Consultants Inc. v. Kennedy (1985), 65 B.C.L.R. 393 (C.A.); Draglund v. McCutcheon (1993), 106 Sask. R. 262 (Q.B.).

UNCITRAL Model Law, supra note 4, art. 8(1).

104 Ibid., art. 7(2).

los This issue will not arise in British Columbia as the International Commercial Arbitration Act, S.B.C. 1986, c. 14 (the "ICAA (B.C.)"), adapted the Model Law, to provide that an application for a stay must be made "before delivery of any pleadings or taking any other step in the proceedings..." (ibid., s. 8(1)). The Supreme Court of British Columbia in Globe Union Industrial Corp. v. G.A.P. Marketing Corp., [1995] 2 W.W.R. 696 interpreted this section. The court rejected the plaintiff's argument, that notwithstanding that the defendant, GAP, had not delivered any pleadings, it had taken a step by filing affidavit material and by appearing to respond to the application. The Court held that defensive procedural steps or the filing of responsive material in interlocutory proceedings does not constitute a step in the proceedings within the meaning of the ICAA (B.C.). The court relied on Roussel-Uclaf v. Searle (G.D.) \& Co., [1978] F.S.R. 95 (Ch.D.) which considered the same provision. The Arbitration Act 1975 (U.K.), 1975, c. 3 also required that an application for a stay be made "before the delivery of any pleadings or taking any other steps in the proceedings..." (ibid., s. 2). 
International commercial arbitration will, of necessity, become a topic of increasing interest to those who deal with the inevitable difficulties that will occur from time to time between international commercial partners.

What we observe today is a trend towards respect for party autonomy and freedom of contract over local interests, biases and policies. Specifically, the recognition of the international context and an increasing reliance on international principles and standards has resulted in the growing harmonization of the laws applicable to the resolution of international commercial disputes. The processes of institutionalization and unification are plainly developing the means to support international commerce and the creation of a world-wide "common law."

Canada's experience after acceding to the New York Convention and the adoption of the Model Law is a good example. The comments of Gerwing J.A. in Saskferco fairly represent the attitude that is needed in all jurisdictions to facilitate dispute resolution between trading partners and to ensure the smooth functioning of international commercial trade:

Public policy carries me to the consideration which I conclude is paramount having regard to the facts of this case, and that is the very strong public policy of this jurisdiction that where parties have agreed by contract that they will have the arbitrators decide their claims, instead of resorting to the Courts, the parties should be held to their contract....

In addition, ... courts must be mindful of the need for consistency between jurisdictions in enforcing international commercial agreements ... Uniformity will foster predictability and in turn international commercial activity within each jurisdiction. ${ }^{107}$ 